\title{
The antioxidant status of the plasma in patients with breast cancer undergoing chemotherapy
}

\author{
Omar M. E. Abdel-Salam ${ }^{1^{*}}$, Eman R. Youness ${ }^{2}, \mathrm{Hafez} \mathrm{F} \mathrm{Hafez}^{3}$ \\ ${ }^{1}$ Department of Toxicology and Narcotics, National Research Centre, Cairo, Egypt; \\ ${ }^{2}$ Department of Medical Biochemistry, National Research Centre, Cairo, Egypt; \\ ${ }^{3}$ Department of Cancer Biology, National Cancer Institute, Cairo University, Cairo, Egypt. \\ Email: ${ }^{*}$ omasalam@hotmail.com
}

Received 1 August 2011; revised 14 September 2011; accepted 25 September 2011.

\begin{abstract}
The aim of the present study was to investigate the status of oxidative stress in the serum of patients affected with cancer breast. Changes in the levels of total antioxidant capacity (TAC), uric acid, malondialdehyde (MDA), nitric oxide (nitrite/nitrate), cupper and iron were measured in serum of patients affected by non-metastatic as well as metastatic cancer breast. Significant decrease in TAC $(32.7 \%-37.5 \%)$, uric acid $(28.1 \%-49.2 \%)$, MDA $(20.7 \%-25.2 \%)$ and nitric oxide $(50.4 \%-61.9 \%)$ were found in both groups of cancer breast patients compared to the control group. Serum $\mathrm{Cu}^{2+}$ concentrations were significantly lower in metastatic cancer patient group compared with both control and non-metastatic cancer groups. $\mathrm{Fe}^{2+}$ in serum was significantly lower in patients with non-metastatic cancer compared to normal subjects and patients with metastatic cancer. Significant differences were also observed between patients with non-metastatic and metastatic cancer breast as regards serum uric acid and nitric oxide that were lower in metastatic compared with nonmetastatic cancer breast.
\end{abstract}

Keywords: Cancer Breast; Chemotherapy; Oxidative Stress; Copper; Iron

\section{INTRODUCTION}

Breast cancer is the most common type of cancer in women and is a leading cause of cancer related deaths worldwide [1]. Cellular damage arising from oxidative stress has been implicated in the initiation and progression of cancer [2,3]. Free radicals and other reactive oxygen species are continuously produced inside the body from oxygen as a result of aerobic metabolism [4]. This is balanced by a number of antioxidant defenses, e.g. intracellular enzymes such as glutathione peroxidase, catalase and superoxide dismutase, metal ion chelators such as transferrin, ferritin and ceruloplasmin, albumin as well as small molecules such as ascorbic acid and vitamin $\mathrm{E}$, which act to maintain the redox balance in the cell. Oxidative stress ensues when these antioxidant mechanisms are overwhelmed by excessive reactive oxygen and nitrogen species generation that damage membrane lipids, proteins and nucleic acids [5]. Studies indicated increased levels of oxidative stress markers in breast cancer patients $[6,7]$, possibly due to the disease process itself and tissue injury. When produced in excess, reactive oxygen species can cause tissue injury. However, tissue injury can itself cause reactive oxygen species generation (e.g., by causing activation of phagocytes or releasing transition metal ions from damaged cells), which may contribute to a worsening of the injury [8]. Studies also indicated that anticancer drugs themselves can induce oxidative stress [9]. It has been suggested that during cancer chemotherapy, electrophilic aldehydes resulting from lipid peroxidation can slow cell cycle progression of cancer cells and cause cell cycle checkpoint arrest and/or inhibit drug-induced apoptosis, effects that may interfere with the ability of antineoplastic agents to exert their optimal cytotoxicity on cancer cells [9]. Total antioxidant capacity of plasma also falls in many types of cancer $[10,11]$, possibly due to the consumption of antioxidants by the excessive free radicals generated or reflecting diminished dietary intake of exogenous antioxidants. Intake of dietary antioxidants might thus be required during chemotherapy, although this is still controversial in view of the evidence suggesting that interference of antioxidants with the action of anticancer drugs [12].

The aim of the present study was to investigate the antioxidant status by measuring serum total antioxidant capacity and urate in patients with breast cancer undergoing chemotherapy. In addition, we also investigated other parameters of oxidative stress, namely serum nitric 
oxide (measured as nitrite/nitrate concentration), malondialdehyde as an index of damage to macromolecules (lipid peroxidation) as well as serum iron and cupper, two important transition metals that undergo redox-cycling reactions. Copper or iron may participate in oxidative stress through redox-cycling between its +2 and +1 oxidation states to generate reactive oxygen species [13].

\section{PATIENTS AND METHODS}

Forty consecutive patients with known cancer breast (non-metastatic and metastatic), with a mean age of 55.1 \pm 1.2 years (range, 38 - 67 years) treated in the National Oncology Institute were studied after they had given informed consent. Twenty patients had non-metastatic cancer breast with a mean age of $55.6 \pm 1.7$ years (range, 39 - 65 years) and twenty had metastatic cancer breast with a mean age of $54.7 \pm 1.8$ years (range, $38-67$ years). Patients were on chemotherapy. The control group comprised 20 healthy females with a mean age of $56 \pm 2.6$ years (range $42-66$ ).

\section{BIOCHEMICAL ANALYSES}

\subsection{Determination of Lipid Peroxides}

Malondialdehyde was determined by measuring thiobarbituric reactive species using the method of Ruiz-Larrea et al. [14] in which the thiobarbituric acid reactive substances react with thiobarbituric acid to produce a red colored complex having peak absorbance at $532 \mathrm{~nm}$.

\subsection{Determination of Total Antioxidant Capacity}

Total serum antioxidant activity was determined by the reaction of antioxidants in the sample with a defined amount of exogenously provide hydrogen peroxide $\left(\mathrm{H}_{2} \mathrm{O}_{2}\right)$. The antioxidants eliminate a certain amount of the provided $\mathrm{H}_{2} \mathrm{O}_{2}$. The residual $\mathrm{H}_{2} \mathrm{O}_{2}$ is determined colorimetric ally by an enzymatic reaction which involves the conversion of 3,5, dichloro-2-hydroxy benzensulphonate to a colored product [15].

\subsection{Determination of Nitric Oxide Metabolites}

Nitric oxide was determined in serum according to the method of Miranda et al. [16]. The level of total nitrite/nitrate in serum samples was expressed in $\mu \mathrm{M}$ and was calculated using the standard curve constructed with the prepared serial dilutions of sodium nitrite.

\subsection{Determination of Uric Acid}

Uric acid concentration was measured by the direct enzymatic method, in which uric acid was oxidized by uricase coupled with peroxidase. Uricase converts uric acid to allantoin and hydrogen peroxide. The hydrogen peroxide formed further reacts with a phenolic compound and 4 aminoantipyrine by the catalytic action of peroxidase to form a red colored quinoneimine dye complex. Intensity of the colour formed is directly proportional to the amount of uric acid present in the sample [17].

\subsection{Determination of Copper and Iron}

Trace element determination of copper and iron was carried out using Varian SpectrAA 220 Flame Atomic Absorption Spectrometer. The spectral lines used for determination were $324.7 \mathrm{~nm}$ for copper and $248.3 \mathrm{~nm}$ for iron.

\subsection{Statistical Analysis}

All results are expressed as means \pm SE. Multiple group comparisons were performed by one way ANOVA followed by Duncan test. Differences between groups and correlation coefficients were considered significant if $P$ $<0.05$.

\section{RESULTS}

Serum iron concentrations were significantly lower in patients with non-metastatic $(0.59 \pm 0.04 \mathrm{mg} / \mathrm{l}$; range 0.3 - 0.9) (28\%) compared with the control group (mean $0.82 \pm 0.07 \mathrm{mg} / \mathrm{l}$; range $0.5-1.33$ ) as well as with patients with metastatic cancer (mean $0.79 \pm 0.07 \mathrm{mg} / \mathrm{l}$; range $0.42-1.22$ ).

Serum copper concentrations did not differ among control (mean $1.73 \pm 0.18 \mathrm{mg} / \mathrm{l}$; range $0.13-6.2$ ) and non-metastatic (mean $1.66 \pm 0.14 \mathrm{mg} / \mathrm{l}$; range $0.3-5.5$ ), but were significantly lower in metastatic cancer patient group (mean $1.09 \pm 0.02 \mathrm{mg} / \mathrm{l}$; range $0.99-1.22)(P<$ $0.05)$. (37\%) compared with the control as well as with the non-metastatic cancer group.

Serum total antioxidant capacity decreased from a mean of $1.48 \pm 0.04 \mu \mathrm{mol} / 1$ (range, $1.3-1.69 \mu \mathrm{mol} / \mathrm{l}$ ) in control group to $0.99 \pm 0.02$ (range, $0.86-1.25 \mu \mathrm{mol} / \mathrm{l}$ ) $(P<0.05)$ in non-metastatic cancer and to $0.92 \pm 0.01$ (range, $0.89-0.99)(P<0.05)$ in metastatic cancer group (Table 1).

Similarly, serum uric acid concentration decreased from a control mean of $5.46 \pm 0.23 \mathrm{mg} / \mathrm{dl}$ (range, 4.4 6.7 ) to $3.92 \pm 0.16 \mathrm{mg} / \mathrm{dl}$ (range, $2.9-6.38$ ) and $2.77 \pm$ $0.13 \mathrm{mg} / \mathrm{dl}$ (range, 2.5 - 2.9) in non-metastatic cancer and metastatic cancer groups, respectively. Patients with metastatic cancer showed significantly lower uric acid values compared with non-metastatic cancer $(P<0.05)$ (Table 1). Uric acid concentrations showed significant correlation with TAC in healthy subjects $(\mathrm{R}=0.797, P=$ $0.006)$. but not in patients with non-metastatic $(\mathrm{R}=$ $-0.006)$ or metastatic cancer $(\mathrm{R}=-0.523, P=0.04)$.

Serum malondialdehyde decreased from a mean of $62.50 \pm 1.70 \mu \mathrm{mol} / 1$ (range, $53.0-71.0 \mu \mathrm{mol} / 1$ ) in control group to $49.50 \pm 2.80($ range, $31.0-73.0 \mu \mathrm{mol} / \mathrm{l})(P<0.05)$ 
Table 1. Serum total antioxidant capacity (TAC), uric acid, malondialdehyde (MDA), nitric oxide (NO), iron and copper in patients with breast cancer.

\begin{tabular}{|c|c|c|c|}
\hline & Control & Non-metastatic cancer & Metastatic cancer \\
\hline TAC $(\mu \mathrm{mol} / \mathrm{l})$ & $1.48 \pm 0.04$ & $0.99 \pm 0.02 *$ & $0.92 \pm 0.01 *$ \\
\hline Uric acid (mg/dl) & $5.46 \pm 0.23$ & $3.92 \pm 0.16^{*}$ & $2.77 \pm 0.13^{*^{+}}$ \\
\hline $\operatorname{MDA}(\mu \mathrm{mol} / \mathrm{l})$ & $62.50 \pm 1.70$ & $49.50 \pm 2.80^{*}$ & $46.60 \pm 1.70^{*}$ \\
\hline NO $(\mu \mathrm{mol} / \mathrm{l})$ & $18.0 \pm 0.44$ & $8.93 \pm 0.54 *$ & $6.85 \pm 0.12^{*^{+}}$ \\
\hline $\mathrm{Fe}^{2+}(\mathrm{mg} / \mathrm{l})$ & $0.82 \pm 0.07$ & $0.59 \pm 0.04 *$ & $0.79 \pm 0.07^{+}$ \\
\hline $\mathrm{Cu}^{2+}(\mathrm{mg} / \mathrm{l})$ & $1.73 \pm 0.18$ & $1.66 \pm 0.14$ & $1.09 \pm 0.02 *^{+}$ \\
\hline
\end{tabular}

Results are mean \pm S.E. Data were analyzed by one way ANOVA and means of different groups were compared by Duncan's multiple range test. $P<0.05$ was considered statistically significant. $*: P<0.05 v s$ control group. $+: P<0.05$ ss the non-metastatic cancer group.

in non-metastatic cancer and to $46.60 \pm 1.70$ (range, 40.0 - 52.0) $(P<0.05)$ in metastatic cancer group (Table 1).

Serum nitric oxide decreased from a mean of $18.00 \pm$ $0.44 \mu \mathrm{mol} / 1$ (range, $16.36-20.62 \mu \mathrm{mol} / \mathrm{l}$ ) in control group to $8.93 \pm 0.54$ (range, $4.69-13.24 \mu \mathrm{mol} / \mathrm{l})(P<$ 0.05 ) in non-metastatic cancer and to $6.85 \pm 0.12$ (range, 6.36 - 7.40) $(P<0.05)$ in metastatic cancer group (table 1). Patients with metastatic cancer showed significantly lower nitric oxide values compared with non-metastatic cancer $(P<0.05)$.

\section{DISCUSSION}

The findings of the present study suggest reduced not only total serum antioxidant capacity, but also oxidative stress in breast cancer patients undergoing chemotherapy. The study indicated a significant decrease in TAC, uric acid, nitric oxide and MDA in cancer breast patients compared to the control group. Moreover, $\mathrm{Fe}^{2+}$ decreased in serum of patients with non-metastatic cancer, while $\mathrm{Cu}^{2+}$ was lower in metastatic cancer patients.

Oxidative stress is defined as an imbalance between reactive oxygen and nitrogen species generation and the anti-oxidant capacity of a cell which includes both antioxidant enzymes and small antioxidant molecules such as the endogenous antioxidant glutathione, as well as antioxidants derived from fruits and vegetables which can normally remove the reactive oxygen and nitrogen species generated by basic physiological functions [3-5]. Studies have indicated increased oxidative stress in patients with different types of cancer [6,7,18-20]. This can be due to increased free radical generation and/or decreased intake of antioxidants. Studies also suggested that chemotherapy (and radiotherapy) is associated with increased formation of reactive oxygen and nitrogen species as well as depletion of endogenous antioxidants, where tissue injury can cause reactive oxygen species generation through activated phagocytes or release of transition metal ions from injured cells [8]. Thus, re- duced free radical trapping capacity of plasma [18]; increased plasma malondialdehyde $[19,20]$, reduced total antioxidant capacity of plasma; reduced total cysteine, glutathione, and homocysteine plasma levels [21] and reduced plasma concentrations of $\alpha$ and $\gamma$-tocopherol [22], ascorbic acid [23], and $\beta$-carotene has been reported during chemotherapy. Meanwhile, a large number of anticancer drugs have been shown to induce oxidative stress [9]. Whether patients on chemotherapy should increase their intake of antioxidants is a matter of debate. It has been suggested that this increase in oxidative stress can interfere with cell cycle progression and drug-induced apoptosis, that are necessary for antineoplastic agents to exert their optimal cytotoxicity on cancer cells, and thus may diminish the effectiveness of the treatment. Some of the side effects caused by antineoplastic agents appear to be caused by increased oxidative stress and can be prevented by certain antioxidants. Administering these supplements during chemotherapy may diminish the development of side effects as well as improve the response to therapy [24].

Nitric oxide $(\mathrm{NO} \bullet)$ is an important intracellular signaling molecule in biological systems with diverse physiological functions including vascular regulation, immunity, and neurotransmission. Nitric oxide is formed from L-arginine by the action of the enzyme nitric oxide synthase (NOS). Three isoforms of NOs have been identified so far, namely, neuronal NOS (nNOS, NOS1), inducible NOS (iNOS, NOS2), and endothelial NOS (eNOS, NOS3). iNOS is most often associated with inflammatory conditions in which it is produced in large amounts by monocyte/macrophage lineage cell types [25, 26]. Studies have suggested a role of nitric oxide in carcinogenesis and tumour propagation [27,28], where eNOS has been shown to be involved in vascular endothelial growth factor (VEGF)-induced tumour angiogenesis [29] and high levels correlated with cisplatin resistance in ovarian cancer cell lines [30]. In contrast, 
genetic polymorphism in eNOS gene with a high level of eNOS mRNA production was related to increased survival in advanced non-small lung cancer patients on chemotherapy [31]. Nitric oxide is itself a free radical and when generated in excess, $\mathrm{NO} \bullet$ can evoke lipid peroxidation and cellular damage by reacting with $\mathrm{O} 2 \cdot$ to form the highly reactive species peroxynitrite (ONOO-). The cell damaging effects of $\mathrm{NO} \bullet$ are the result of peroxynitrite formation which can cause induce lipid peroxidation, DNA base nitration [26], oxidize methionine and sulfhydryl residues in proteins [8]. In the present study, nitric oxide (measured as nitrite/nitrate concentrations) was significantly reduced in patients with cancer breast on chemotherapy. Similar results were provided by Güler et al. [32], who demonstrated decreased plasma total nitrite level after chemotherapy. Moreover, in the present study serum nitric oxide was lower in metastatic compared with non-metastatic cancer breast.

In recent years, measurement of total antioxidant capacity of tissues and plasma has been widely used in several human diseases including cancer. It has been suggested that in monitoring the antioxidant defenses, the body's non-enzymatic antioxidant network can be assessed through the measurement of total antioxidant capacity (TAC), defined as the moles of radicals neutralized per $1 \mathrm{~L}$ of tested sample [33]. Low total antioxidant capacity could be indicative of oxidative stress or increased susceptibility to oxidative damage [15]. The TAC measurement does not represent the sum of activities of antioxidants; however, it could be used for clinical diagnosis, as it is an easy and less time-consuming procedure [34]. Studies have indicated decreased plasma total antioxidant capacity in different forms of cancer e.g., colon cancer [35], lung cancer [23] and breast cancer [19]. In the present study, TAC in serum showed significant decrease, although there was no difference in patients with non-metastatic and metastatic cancer. Other researchers reported a significant decrease of plasma TAC after treatment of children with malignancy with standard chemotherapy which was associated with increased ROS release from PMNs and monocytes [36]. The reduction in TAC could reflect consumption of endogenous antioxidants by free radicals generation by the disease process or chemotherapy itself. Insufficient dietary intake of exogenous antioxidants during the treatment period might have also contributed

Uric acid, the end product of purine metabolism is considered an important antioxidant contributing to the total antioxidant capacity of the plasma [37]. Single-strand DNA breaks produced in isolated rat liver nuclei by xanthine oxidase or acetaldehyde plus $\mathrm{Fe}$ (II) were inhibited by uric acid [38]. Uric acid has been shown to form stable co-ordination complexes with iron ions. Formation of urate- $\mathrm{Fe}^{3+}$ complexes dramatically inhibits $\mathrm{Fe}^{3+}$-catalysed ascorbate oxidation, as well as lipid peroxidation [39]. Uric acid also can scavenge peroxyl, hydroxyl and superoxide radicals and inhibit oxidative protein, DNA and lipids damage [40,41]. In healthy subjects, systemic administration of uric acid which raised serum urate concentration from was associated with increased serum antioxidant capacity and reduced oxidative stress during acute physical exercise [42]. Plasma urate has been associated with a lower risk of Parkinson's disease in men [43]. Dietary and genetic determinants of urate have also been linked to a reduced risk or delayed onset of Parkinson's disease [44]. In the present study, significant decrease in uric acid has been observed in breast cancer patients on chemotherapy; values were in addition lower in metastatic cancer compared with non-metastatic cancer patients. This reduction in serum uric acid might have also contributed to the lower level of decrease of TAC observed in these patients.

Copper and iron are two redox-active metals of biological significance. Owing to their ability to donate electrons to oxygen, increased copper and iron levels can lead to the formation of hydroxyl radicals and hydroxyl anions via the Fenton Reaction $\left(\mathrm{Fe}^{2+}+\mathrm{H}_{2} \mathrm{O}_{2} \rightarrow \mathrm{Fe}^{3+}+\right.$ $\left.\mathrm{OH} \cdot+\mathrm{OH}^{-}\right)\left(\mathrm{Cu}^{2+}+\mathrm{H}_{2} \mathrm{O}_{2} \rightarrow \mathrm{Cu}^{1+}+\mathrm{OH} \cdot+\mathrm{OH}^{-}\right)[45]$. These redox-active metals could be released by reactive oxygen species from their storage proteins ferritin and caeruloplasmin and involved in a Fenton-like reaction leading to further production of oxidative radicals. The resultant radical-mediated cytotoxicity (membrane lipid peroxidation and oxidative modification of various membrane and associated proteins) may contribute to cellular damage observed in this condition $[8,46]$. Antioxidants are thus of fundamental importance to control and prevent the detrimental formation of reactive oxygen species generated via Fenton chemistry. One more serious effect of copper (as well as cobalt, nickel, chromium, lead, mercury, tin, and vanadate) is its ability to activate estrogen receptor $\alpha$ unit (ER $\alpha$ ) by forming a high affinity complex with the hormone-binding domain [47]. Copper is increased in cancer tissue [48], possibly due to increased angiogenesis [49], while copper deficiency has been suggested as an anti-cancer strategy [50]. Studies linked increased serum iron to the development of cancer [51,52]. Ulbrich et al. [53] suggested that elevated serum ferritin might indicate the presence of malignant disease and could be regarded as a predictor of positive lymph node involvement in patients with breast cancer prior to surgery. Elevation of the levels of iron, copper (and zinc) has been detected in carcinomatous breast tissue compared to healthy tissue [54]. In primary invasive ductal carcinoma of breast, tumour regions were found to have a higher fraction of $\mathrm{Cu}^{2+}$ compared to the 
normal samples [55]. Elliott et al. [56], however, noted that in breast cancer patients $43 \%$ had depressed serum iron levels. On the other hand, elevated non-protein bound iron in plasma was reported after starting chemotherapy accompanied by significant rise in total plasma iron and decreased vitamin plasma $\mathrm{C}$ and $\mathrm{E}$, suggesting consumption of antioxidants [57]. In the present study, serum $\mathrm{Cu}^{2+}$ concentrations were lower in patients with metastatic cancer, whereas $\mathrm{Fe}^{2+}$ level decreased in patients with non-metastatic cancer.

The free-radical oxidation of polyunsaturated fatty acids in biological systems is known as lipid peroxidation. The detection and measurement of lipid peroxidation is the evidence most frequently cited to support the involvement of free-radical reactions in toxicology and disease. Aldehydes such as malondialdehyde, 4-hydroxynonenal, and acrolein resulting from lipid peroxidation can bind covalently to proteins, thereby altering their function which results in enzyme inhibition and alteration of the structure of cellular receptors and cellular damage [5]. In the present study, lipid peroxidation in the form of malondialdehyde (MDA) was significantly decreased to comparable extent in both non-metastatic and metastatic cancer patients compared with healthy subjects. These results point to decreased oxidative stress in those patients. Similarly, Alagöl et al. [58] found lower plasma MDA levels in patients with advanced breast cancer, while Gönença et al. [59] detected decreased serum and tissue MDA levels in breast cancer patients compared to those with benign breast lesions. This decrease in malondialdehyde plasma concentration was also observed in patients with various carcinomas. Malondialdehyde plasma concentration decreased with severity of pathology and tumor size [60]. In contrast, the findings of Sener et al. [19] and Val Carneiro et al. [20] suggested increased MDA in patients with breast cancer compared with healthy subjects. The reduction in lipid peroxidation observed in the present study does not suggest increased level of oxidative stress in patients with breast cancer undergoing chemotherapy. The reduction in TAC might in this condition reflect consumption of endogenous as well as exogenous antioxidants in free radical reactions. Saintot et al. [61] found an inverse relationship between plasma lipoperoxides (MDA) and tumor size at diagnosis, together with higher lipoperoxide levels in node-negative tumors than in node-positive ones. High plasma lipoperoxides appeared to be a factor in poor prognosis for breast cancer-specific survival and disease-free survival, respectively, independent of tumor characteristics at diagnosis.

In summary, the findings in the present study suggested reduced not only total serum antioxidant capacity, but also oxidative stress in patients with cancer breast undergoing chemotherapy.

\section{REFERENCES}

[1] Coughlin, S.S., and Ekwueme, D.U. (2009) Breast cancer as a global health concern. Cancer Epidemiology, 33, 315-318. doi:10.1016/i.canep.2009.10.003

[2] Noda, N. and Wakasugi, H. (2001) Cancer and oxidative stress. Japan Medical Association Journal, 44, 535-539.

[3] Halliwell, B. (2007) Oxidative stress and cancer: Have we moved forward? Biochemical Journal, 401, 1-11. doi:10.1042/BJ20061131

[4] Halliwell, B. and Gutteridge, J.M.C. (2006) Free radicals in biology and medicine, Edition $4^{\text {th }}$, Clarendon Press, Oxford.

[5] Halliwell, B. and Gutteridge, J.C. (1995) The definition and measurement of antioxidants in biological systems. Free Radical Biology and Medicine, 18, 125-126. doi:10.1016/0891-5849(95)91457-3

[6] Kasapović, J., Pejić, S., Stojiljković, V., Todorović, A., Radošević-Jelić, L., Saičić, Z.S. and Pajović, S.B. (2010) Antioxidant status and lipid peroxidation in the blood of breast cancer patients of different ages after chemotherapy with 5-fluorouracil, doxorubicin and cyclophosphamide. Clinical Biochemistry, 43, 1287-1293. doi:10.1016/i.clinbiochem.2010.08.009

[7] Yeon, J.Y., Suh, Y.J., Kim, S.W., Baik, H.W., Sung, C.J., Kim, H.S. and Sung, M.K. (2011) Evaluation of dietary factors in relation to the biomarkers of oxidative stress and inflammation in breast cancer risk. Nutrition, 27, 912-918. doi:10.1016/j.nut.2010.10.012

[8] Aruoma, O.I. (1998) Free radicals, oxidative stress, and antioxidants in human health and disease. Journal of the American Oil Chemists' Society, 75, 199-212.

[9] Conklin, K.A. (2004) Chemotherapy-Associated oxidative stress: Impact on chemotherapeutic effectiveness. Integrative Cancer Therapies, 3, 294. doi: $10.1177 / 1534735404270335$

[10] Ladas, E.J., Jacobson, J.S., Kennedy, D.D., Teel, K., Fleischauer, A. and Kelly, K.M. (2004) Antioxidants and cancer therapy: A systematic review. Journal of Clinical Oncology, 22, 517-528. doi:10.1200/JCO.2004.03.086

[11] Crohns, M., Liippo, K., Erhola, M., Kankaanranta, H., Moilanen, E., Alho, H. and Kellokumpu-Lehtinen, P. (2009) Concurrent decline of several antioxidants and markers of oxidative stress during combination chemotherapy for small cell lung cancer. Clinical Biochemistry, 42, 1236-1245. doi:10.1016/j.clinbiochem.2009.05.003

[12] Turchi, J.J. (2006) Nitric oxide and cisplatin resistance: No easy answers. Proceedings of the National Academy of Sciences, 103, 4337-4338. doi: $10.1073 /$ pnas.0601001103

[13] Valko, M., Rhodes, C.J., Moncola, J., Izakovic, M. and Mazura, M. (2006) Free radicals, metals and antioxidants in oxidative stress-induced cancer. Chemico-Biological Interactions, 160, 1-40. doi:10.1016/j.cbi.2005.12.009

[14] Ruiz-Larrea, M.B., Leal, A.M., Liza, M., Lacort, M. and De Groot, H. (1994) Antioxidant effects of estradiol and 2-hydroxyestradiol on iron-induced lipid peroxidation of rat liver microsomes. Steroids, 59, 383-388. doi:10.1016/0039-128X(94)90006-X 
[15] Koracevic, D., Koracevic, G., Djordjevic, V., Andrejevic, S. and Cosic, V. (2001) Method for the measurement of antioxidant activity in human fluids. Journal of Clinical Pathology, 54, 356-361. doi:10.1136/jcp.54.5.356

[16] Miranda, K.M., Espey, M.G. and Wink, D.A. (2001) A rapid, simple spectrophotometric method for simultaneous detection of nitrate and nitrite. Nitric Oxide, 5, 62-71 doi:10.1006/niox.2000.0319

[17] Fossati, P., Prencipe, L. and Berti, G. (1980) Use of 3,5dichloro-2-hydroxybenzenesulfonic acid/4-aminophenazone chromogenic system in direct enzymic assay of uric acid in serum and urine. Clinical Chemistry, 26, 227-231.

[18] Dürken, M., Agbenu, J., Finckh, B., Hübner, C., Pichlmeier, U., Zeller, W., Winkler, K., Zander, A. and Kohlschütter, A. (1995) Deteriorating free radical trapping capacity and antioxidant status in plasma during bone marrow transplantion. Bone Marrow Transplant, 15, 757-762.

[19] Sener, D.E., Gönenç, A., Akinci, M. and Torun, M. (2007) Lipid peroxidation and total antioxidant status in patients with breast cancer. Cell Biochemistry and Function, 25, 377-382. doi:10.1002/cbf.1308

[20] Do Val Carneiro, J.L., Nixdorf, S.L., Mantovani, M.S., Da Silva Do Amaral Herrera, A.C., Aoki, M.N., Amarante, M.K., Fabris, B.A., Pelegrinelli Fungaro, M.H. and Ehara Watanabe, M.A. (2009) Plasma malondialdehyde levels and CXCR4 expression in peripheral blood cells of breast cancer patients. Journal of Cancer Research and Clinical Oncology, 135, 997-1004. doi:10.1007/s00432-008-0535-7

[21] Lauterburg, B.H., Nguyen, T., Hartmann, B., Junker, E., Kupfer, A. and Cerny, T. (1994) Depletion of total cysteine, glutathione, and homocysteine in plasma by ifosfamide/mesna therapy. Cancer Chemotherapy and Pharmacology, 35, 132-136. doi:10.1007/BF00686635

[22] Jonas, C.R., Puckett, A.B., Jones, D.P., Griffith, D.P., Szeszycki, E.E., Bergman, G.F., Furr, C.E., Tyre, C., Carlson, J.L., Galloway, J.R., Blumberg, J.B. and Ziegler, T.R. (2000) Plasma antioxidant status after high-dose chemotherapy a randomized trial of parenteral nutrition in bone marrow transplantation patients. The American Journal of Clinical Nutrition, 72, 181-189.

[23] Erhola, M., Kellokumpu-Lehtinen, P., Metsa-Ketela, T., Alanko, K. and Nieminen, M.M. (1996) Effects of anthracyclin-based chemotherapy on total plasma antioxidant capacity in small cell lung cancer patients. Free Radical Biology and Medicine, 21, 383-390. doi:10.1016/0891-5849(96)00041-X

[24] Rabovsky, A.B., Komarov, A.M., Ivie, J.S. and Buettner, G.R. (2010) Minimization of free radical damage by metal catalysis of multivitamin/multimineral supplements. Nutrition Journal, 9, 61. doi:10.1186/1475-2891-9-61

[25] Moncada, S., Palmer, R. M. J. and Higgs, E. A. (1991) Nitric oxide: Physiology, pathophysiology, and pharmacology. Pharmacological Reviews, 43, 109-142.

[26] Moncada, S. and Bolanos, J.P. (2006) Nitric oxide, cell bioenergetics and neurodegeneration. Journal of Neurochemistry, 97, 1676-1689. doi:10.1111/j.1471-4159.2006.03988.x

[27] Yagihashi, N., Kasajima, H., Sugai, S., Matsumoto, K., Ebina, Y., Morita, T., Murakami, T. and Yagihashi, S.
(2000) Increased in situ expression of nitric oxide synthase in human colorectal cancer. Virchows Arch, 436, 109-114. doi:10.1007/PL00008208

[28] Jadeski, L.C., Chakraborty, C. and Lala, P.K. (2003) Nitric oxide-mediated promotion of mammary tumour cell migration requires sequential activation of nitric oxide synthase, guanylate cyclase and mitogen-activated protein kinase. International Journal of Cancer, 106, 496-504. doi:10.1002/ijc. 11268

[29] Duda, D.G., Fukumura, D. and Jain, R.K. (2004) Role of eNOS in neovascularization: No for endothelial progenitor cells. Trends in Molecular Medicine, 10, 43-145. doi:10.1016/j.molmed.2004.02.001

[30] Leung, E.L., Fraser, M., Fiscus, R.R. and Tsang, B.K. (2008) Cisplatin alters nitric oxide synthase levels in human ovarian cancer cells: Involvement in p53 regulation and cisplatin resistance. British Journal of Cancer, 98, 1803-1809. doi:10.1038/sj.bjc.6604375

[31] Fujita, S., Masago, K., Hatachi, Y., Fukuhara, A., Hata, A., Kaji1, R., Kim, Y.H., Mio, T., Mishima, M. and Katakami, N. (2010) Genetic polymorphisms in the endothelial nitric oxide synthase gene correlate with overall survival in advanced non-small-cell lung cancer patients treated with platinum-based doublet chemotherapy. BMC Medical Genetics, 11, 167. doi:10.1186/1471-2350-11-167

[32] Güler, E., Balat, A., Çekmen, M., Kılınç, M., Sivasli, E., Yürekli, M. and Duman, C. (2006) The effects of anticancer drugs on levels of nitric oxide and adrenomedullin. The Turkish Journal of Pediatrics, 48, 202-208.

[33] Serafini, M. and Del Rio, D. (2004) Understanding the association between dietary antioxidants, redox status and disease: Is the total antioxidant capacity the right tool? Redox Report, 9, 145-152. doi:10.1179/135100004225004814

[34] Kankofer, M., Lipko, J. and Zdunczyk, S. (2005) Total antioxidant capacity of bovine spontaneously released and retained placenta. Pathophysiology, 11, 215-219. doi:10.1016/j.pathophys.2005.01.001

[35] Di Giacomo, C., Acquaviva, R., Lanteri, R., Licata, F., Licata, A. and Vanella, A. (2003) Nonproteic antioxidant status in plasma of subjects with colon cancer. Experimental Biology and Medicine (Maywood), 228, 525-528.

[36] Papageorgiou, M., Stiakaki, E., Dimitriou, H., Malliaraki, N., Notas, G., Castanas, E. and Kalmanti, M. (2005) Cancer chemotherapy reduces plasma total antioxidant capacity in children with malignancies. Leukemia Research, 29, 11-16. doi:10.1016/j.leukres.2004.04.017

[37] Ames, B.N., Cathcart, R., Schwiers, E. and Hochstein, P. (1981) Uric acid provides an antioxidant defense in humans against oxidant- and radical-caused aging and cancer: A hypothesis (lipid peroxidation/ascorbic acid/primate evolution/erythrocyte aging). Proceedings of the National Academy of Sciences, 78, 6858-6862. doi:10.1073/pnas.78.11.6858

[38] Cohen, A.M., Aberdrotha, R.E. and Hochstein, P. (1984) Inhibition of free radical-induced DNA damage by uric acid. FEBS Letters, 174, 147-150. doi:10.1016/0014-5793(84)81094-7

[39] Davies, K.J., Sevanian, A.S., Muakkassah-Kelly, S.F. and Hochstein, P. (1986) Uric acid-iron ion complexes: A new aspect of the antioxidant functions of uric acid. 
Biochemical Journal, 235, 747-754.

[40] Muraoka, S. and Miura, T. (2003) Inhibition by uric acid of free radicals that damage biological molecules. Toxicology and Pharmacology, 93, 284-289. doi:10.1111/j.1600-0773.2003.pto930606.x

[41] Stinefelt, B., Leonard, S.S., Blemings, K.P., Shi, X. and Klandorf, H. (2005) Free radical scavenging, DNA protection, and inhibition of lipid peroxidation mediated by uric acid. Annals of Clinical \& Laboratory Science, 35, $37-45$.

[42] Waring, W.S., Convery, A., Mishra, V., Shenkin, A., Webb, D.J. and Maxwell, S.R.J. (2003) Uric acid reduces exercise-induced oxidative stress in healthy adults. Clinical Science, 105, 425-430. doi:10.1042/CS20030149

[43] Gao, X., Chen, H., Choi, H.K., Curhan, G., Schwarzschild, M.A. and Ascherio, A. (2008) Diet, urate, and parkinson's disease risk in men. American Journal of Epidemiology, 167, 831-838. doi:10.1093/aje/kwm385

[44] Cipriani, S., Chen, X. and Schwarzschild, M.A. (2010) Urate: A novel biomarker of Parkinson's disease risk, diagnosis and prognosis. Biomarks in Medicine, 4, 701712. doi: $10.2217 / \mathrm{bmm} .10 .94$

[45] Halliwell, B., Gutteridge, J.M.C. (1984) Oxygen toxicity, oxygen radicals, transition metals and disease. Biochemistry, 219, 1-14.

[46] Fisher, A.E.O. and Naughton, D.P. (2003) Redox-active metal ions and oxidative stress: Therapeutic implications. Proceedings of the Indian National Science Academy, B69, 453-460.

[47] Martin, M.B., Reiter, R., Pham, T., Avellanet, Y.R., Camara, J., Lahm, M., Pentecost, E., Pratap, K., Gilmore, B.A., Divekar, S., Dagata, R.S., Bull, J.L. and Stoica, A. (2003) Estrogen-Like activity of metals in mcf-7 breast cancer cells. Endocrinology, 144, 2425. doi:10.1210/en.2002-221054

[48] Kuo, H.W., Chen, S.F., Wu, C.C., Chen, D.R. and Lee, J.H. (2002) Serum and tissue trace elements in patients with breast cancer. Biological Trace Element Research, 89, 1-11. doi:10.1385/BTER:89:1:1

[49] Brewer, G.J. (2001) Copper control as an antiangiogenic anticancer therapy: Lessons from treating Wilson's disease. Experimental Biology and Medicine (Maywood), 226, 665-673.

[50] Goodman, V.L., Brewer, G.J. and Merajver, S.D. (2004) Copper deficiency as an anti-cancer strategy. Endocrine-Related Cancer, 11, 255-263. doi:10.1677/erc.0.0110255

[51] Elmberg, M., Hultcrantz, R., Ekbom, A., Brandt, L., Olsson, S. and Olsson, R. (2003) Cancer risk in patients with hereditary hemochromatosis and in their first-degree relatives. Gastroenterology, 125, 1733-1741. doi:10.1053/i.gastro.2003.09.035

[52] Wu, T., Sempos, C.T., Freudenheim, J.L., Muti, P. and Smit, E. (2004) Serum iron, copper and zinc concentrations and risk of cancer mortality in US adults. Annals of Epidemiology, 14, 195-201. doi:10.1016/S1047-2797(03)00119-4

[53] Ulbrich, E.J., Lebrecht, A., Schneider, I., Ludwig, E., Koelbl, H. and Hefler, L.A. (2003) Serum parameters of iron metabolism in patients with breast cancer. Anticancer Research, 23(6D), 5107-5109.

[54] Geraki, K., Farquharson, M.J. and Bradley, D.A. (2002) Concentrations of $\mathrm{Fe}, \mathrm{Cu}$ and $\mathrm{Zn}$ in breast tissue: A synchrotron XRF study. Physics in Medicine and Biology, 47, 2327-2339. doi:10.1088/0031-9155/47/13/310

[55] Farquharson, M.J., Al-Ebraheem, A., Falkenberg, G. Leek, R., Harris, A.L. and Bradley, D.A. (2008) The distribution of trace elements $\mathrm{Ca}, \mathrm{Fe}, \mathrm{Cu}$ and $\mathrm{Zn}$ and the determination of copper oxidation state in breast tumour tissue using muSRXRF and muXANES. Physics in Medicine and Biology, 53, 3023-3037. doi:10.1088/0031-9155/53/11/018

[56] Elliott, R.L., Head, J.F. and McCoy, J.L. (1994) Relationship of serum and tumor levels of iron and ironbinding proteins to lymphocyte immunity against tumor antigen in breast cancer patients. Breast Cancer Research and Treatment, 30, 305-309. doi:10.1007/BF00665972

[57] Weijl, N.I., Elsendoorn, T.J., Moison, R.M.W., Lentjes, E.G.W.M., Brand, R., Berger, H.M. and Osanto, S. (2004) Non-protein bound iron release during chemotherapy in cancer patients. Clinical Science, 106, 475-484. doi:10.1042/CS20030271

[58] Alagöl, H., Erdem, E., Sancak, B., Turkmen, G., Camlibel, M. and Bugdayci, G. (1999) Nitric oxide biosynthesis and malondialdehyde levels in advanced breast cancer. Australian and New Zealand Journal of Surgery, 69, 647-650. doi:10.1046/j.1440-1622.1999.01656.x

[59] Gönença, A., Ertena, D., Aslanb, S., Akıncıb, M., Şimşeka, B. and Toruna, M. (2006) Lipid peroxidation and antioxidant status in blood and tissue of malignant breast tumor and benign breast disease. Cell Biology International, 30, 376-380. doi:10.1016/j.cellbi.2006.02.005

[60] Gerber, M., Astre, C., Ségala, C., Saintot, M., Scali, J., Simony-Lafontaine, J., Grenier, J. and Pujol, H. (1996) Oxidant-antioxidant status alterations in cancer patients: Relationship to tumor progression. Journal of Nutrition, 126,1201S-1207S.

[61] Saintot, M., Mathieu-Daude, H., Astre, C., Grenier, J., Simony-Lafontaine, J. and Gerber, M. (2002) Oxidantantioxidant status in relation to survival among breast cancer patients. International Journal of Cancer, 97, 574-579. doi:10.1002/ijc.10099 